\title{
Value Education under a Community with a Shared Future for Mankind
}

\author{
Bo Feng* \\ Center for Ideological and Political Education, Northeast Normal University, Changchun 130024, China \\ *Corresponding Author email: fengb791@nenu.edu.cn
}

Keywords: the community with a shared future for mankind; value education

\begin{abstract}
The changing world order has shaped and influenced the form of international cooperation in higher education. The world situation and world order in higher education profoundly affect the form and scope of international exchange and cooperation. To build a community with a shared future for mankind requires human common value identification. How to promote value identification through value education is a topic that must be seriously studied. In the new stage of the change of world order, as a new view of the world order with Chinese characteristics, based on historical experience and new trend of the times development, China proposes to build a community with a shared future for mankind. The concept has a normative and leading role in international cooperation in higher education. The common value of human beings is not the universal value, but also different from the narrow national value. It is based on respect for the value of the nation, and is the commonality and unity based on the diversity of value. To guide the international cooperation in higher education with the community with a shared future for mankind, it is required to transcend the goal of international cooperation in the light of "national interests", safeguard equal status and autonomy, recognize and respect differences, and eliminate the "center periphery" structure in international cooperation. The common value education of human must regard education as the common interest of the world, not only the education of human basic value, but also the multi understanding education of national and national values. It is necessary to carry out the education of global sense of responsibility between nations and between people, and also to carry out the value education of harmony between man and nature.
\end{abstract}

\section{Introduction}

The eighteen major reports of the party emphasize that mankind has only one earth, and every country coexists with one world, and we must advocate the sense of "community of human destiny"[1]. In twenty-first Century, with the increasingly close ties of the world and the changes brought about by politics, economy, society and technology [2]. In particular, governments and educational institutions have organized to promote international exchanges and cooperation in higher education [3]. According to Adler and Barnett, the community has three characteristics, that is, the member states in the common body share common identities and values [4]. The direct interaction between the member states can be conducted in many directions, and the community shows a certain degree of reciprocity and altruism [5]. In the 2011 white paper on China's peaceful development, it is proposed that we should seek a new connotation of common interests and common values of mankind in the new perspective of "destiny community"[6]. There is a new incentive behind the international cooperation in higher education. Enhancing the international reputation of the institutions, improving the quality of personnel training and internationalization, and promoting mutual learning among different civilizations are often regarded as new driving forces for cooperation [7]. Thus, the construction of the community of human destiny has both the needs of common interests and the common value identity of mankind. How to promote value identification through value education and promote the construction of the community of human destiny is a subject that must be seriously studied. The future of higher education cooperation in the world has become a realistic problem that the state and higher education institutions can not avoid. 
The basic features of the current international situation are world multipolarization, economic globalization, cultural diversity and social informatization[8]. Whether active layout or passive response, higher education international cooperation has become an action strategy that higher education institutions must attach importance to in the context of globalization [9]. Food security, shortage of resources, climate change, network attack, population explosion, environmental pollution, disease epidemic, transnational crime and other global non-traditional security problems emerge in endlessly [10]. It poses a severe challenge to international order and human survival. No matter where people are, whether they are willing or not, they are actually in a community of destiny. In recent decades, China's higher education has made considerable progress, and the educational practice of the Chinese government and higher education institutions has been integrated into international cooperation and global participation. At the same time, a global value concept aimed at meeting the common challenges of mankind has begun to take shape and gradually gained international consensus. With the change of world political and economic situation, the world is faced with instability and uncertainty, and global problems are increasing. Globalization and the trend of anti-globalization all over the world will challenge international cooperation in higher education. This global value includes interdependent concepts of international power, common interests, sustainable development and global governance.

\section{The Construction of the Community with a Shared Future for Mankind}

Despite the surging tide of globalization in the western countries, there is even pessimism about the end of globalization and the theory of death. But it is foreseeable that the trend of anti-globalization in the future will not reverse globalization, and the trend of globalization is still irresistible. Rather than globalisation, the new wave of globalization is emerging. There is a subject of value, namely, the value of "who" to meet the needs of "who". The common value of mankind is the value of "human community", which transcends a single nation, state and society. It reflects the common needs of all nations, countries and regions in the world and reflects the common interests of mankind. Among them, the emerging economies led by China are becoming an important driving force for the new round of globalization. A similar view is that the wave of economic globalization will not fade itself, but the question of who will lead it and what doctrine (Si Chao) will lead it. Therefore, the formation of the common value of mankind is based on the emergence of the human community. The common value of mankind is not only the objective requirement of cultural convergence in the new era of globalization, but also the key to Chinese government's efforts to build a community of human destiny.

The generation of people's ideas and concepts is inseparable from the investigation of their social relations. Some scholars have expressed another concern: although globalization will not be reversed in a short time. But it is affected by the resurgence of isolationism, nationalism and Populism in many developed countries. The global governance mechanism is likely to fail to some extent. Scholars call it "global governance failure". The first form of human social development is the dependence of human beings. Marx summed it up as a "naturally formed community". Its performance, on the one hand, is the attachment to nature. In primitive human society, the development level of productive forces is low, and survival depends mainly on the gift of nature, and the natural integration of man and nature. On the other hand, people are dependent on people. It was formed naturally through blood relationship and geopolitical relationship. It is manifested as "family and expansion into tribal families, or through intermarriage between families [tribes], or tribal associations". Global governance problems such as climate change, public health, network security and refugee problems have been difficult. Facing all kinds of chaos, scholars have pointed out that the current global social and political chaos is just the beginning of greater turbulence. In the trend of globalization, it is the most urgent task for mankind to proceed with the trend and to manage in disorder.

The community of destiny is also a community, but it obviously does not advocate the integration of countries. Therefore, it is far from the tightly coupled security community. It can only correspond to loosely coupled multiple security communities. Focusing on the development process of the 
"security community", a three level analysis is made, with different characteristics set at each level. Inspected the current "fate community" process to satisfy different levels of characteristics. (see Table 1)

Table 1 The current "destiny community" process satisfies the "security community" level characteristics

\begin{tabular}{|c|c|c|c|}
\hline & \multicolumn{2}{|c|}{ Hierarchical characteristics } & The characteristic satisfaction of the current "destiny \\
\hline \multirow[t]{4}{*}{ First level } & \multicolumn{2}{|c|}{ Technical progress } & Community" process \\
\hline & \multicolumn{2}{|c|}{ Economic factors } & Economic globalization \\
\hline & \multicolumn{2}{|c|}{ External threat } & All kinds of global problems \\
\hline & \multirow{2}{*}{$\begin{array}{l}\text { Structural } \\
\text { category }\end{array}$} & Power & China as a driving country and a core country \\
\hline \multirow{4}{*}{ Second level } & & Knowledge & Common values of fate (symbiosis) \\
\hline & \multirow{3}{*}{$\begin{array}{l}\text { Process } \\
\text { category }\end{array}$} & Contact & $\begin{array}{c}\text { Economic, political, security, cultural, ecological and } \\
\text { other multi-dimensional exchanges }\end{array}$ \\
\hline & & Organization & $\begin{array}{c}\text { The United Nations has played an important role in not } \\
\text { yet establishing its own organization. }\end{array}$ \\
\hline & & $\begin{array}{l}\text { Social } \\
\text { learning }\end{array}$ & In the process of his domestically \\
\hline \multirow{2}{*}{ Third level } & \multirow{2}{*}{\multicolumn{2}{|c|}{$\begin{array}{c}\text { Mutual trust } \\
\text { Collective identity }\end{array}$}} & Need to be strengthened \\
\hline & & & To be established \\
\hline
\end{tabular}

With the continuous development of social productive forces, people's dependency relationship has been gradually abandoned and replaced by "human independence based on the dependence of things". From the external conditions, globalization has made the interconnections between countries become more and more deepened. Globalization is a reality of the change of life and space that we are facing. "Events in remote areas... All of us are more direct and faster than ever before. In turn, the consequences of decisions we make as individuals are often global. It is manifested in the relationship between man and nature. People not only continue to rely on natural grants, but also consciously transform nature in order to enrich their own material conditions. It is precisely because of human transformation of nature that people have gained more material wealth, highlighting the subjectivity and initiative of man in the face of nature. If countries still focus on domestic affairs with traditional thinking, they will be limited to solving global problems from the perspective of confrontation and competition. More and more global problems will accumulate and ferment if we are entangled in our national interests. China has taken the initiative to establish a partnership with other countries for peaceful coexistence and cooperation and, in particular, to properly deal with the relations between countries and regions with their own conflicts of interest, with an open and friendly attitude.

The proposition of the community of human destiny highlights the image of China's responsible big country. In the context of China's rapid development, some western countries are worried that China will challenge the Western dominated international system by means of war and other means, and spread China's challenge to its hegemony on the global scale. The transformation of man to nature enables an individual to acquire an independent material foundation, and the interest of commodity economy activates the desire of individuals to occupy more surplus products. Therefore, mankind has fallen into the general state of war of "man to man is wolf". The false community formed by former individuals is always independent of individuals. This community is a union of one class against another. Therefore, for the ruling class, it is not only a totally illusory community, but also a new fetter. In response to the "China Threat Theory" of the outside world, it will reduce the worries of other countries and regions on China's rise. China gradually adjusts its own national identity to alleviate the overreaction of the world to China. The responsible big country has increasingly become the new orientation of the construction of China's national identity. Therefore, the community of modern society is a "false community". If there is common value, it is also a strong country that forces vulnerable countries to accept with their own value. This value is not a common value of mankind, but a strong national value under the guise of universal values. It excludes the diversity of world 
civilization and values, forcing other countries to observe the only value, resulting in a conflict between civilization and value.

\section{The Connotation of Human Common Value}

There is no doubt that the development of human society needs value guidance, otherwise it is chaotic and chaotic. But what kind of value is needed? Different stages of social development are different. General secretary Xi Jinping explained the four connotations of the community of human destiny in the 2015 annual meeting of the Boao forum for Asia. As shown in Table 2.

Table 2 The four connotations of the community of human destiny

\begin{tabular}{|c|c|}
\hline $\begin{array}{l}\text { Four } \\
\text { connotation } \\
\mathrm{s}\end{array}$ & The key to the community of human destiny \\
\hline 1 & $\begin{array}{l}\text { We must respect the social system and development path chosen by all } \\
\text { countries and respect each other's core interests and major concerns. }\end{array}$ \\
\hline 2 & Adhere to cooperation and win-win and common development \\
\hline 3 & $\begin{array}{l}\text { Abandon the Cold War mentality and uphold common, comprehensive, } \\
\text { cooperative and sustainable security. }\end{array}$ \\
\hline 4 & $\begin{array}{l}\text { We should adhere to the different civilizations, and exchange and learn } \\
\text { from each other. In modern society, individual value consciousness is } \\
\text { awakened, but this consciousness is isolated and monadic. }\end{array}$ \\
\hline
\end{tabular}

Therefore, there is only the value of trying to dominate others, and the various value subjects are in an unequal dominance and dominance. Even the extremes of confrontation, the clash of civilizations. The ideological system of human destiny includes logical starting points in many aspects. As shown in Table 3.

Table 3 Different views on the thought of the community of human destiny

\begin{tabular}{cc}
\hline $\begin{array}{c}\text { Three different } \\
\text { views }\end{array}$ & $\begin{array}{c}\text { The system of the thought of the community } \\
\text { of human destiny }\end{array}$ \\
\hline 1 & A "harmony but different" view \\
2 & The "common interest" view \\
\hline
\end{tabular}

The first is the view of "harmony but different". Peace and development have always been the goal of China's pursuit. The cultural view embodied in the human destiny community is to establish the order of coexistence and coexistence among different cultures in the world, and emphasize the principle of mutual respect and study among various cultures. The concept of "harmony but difference" also contains equality between big and small countries, no matter "mainstream culture" and "non mainstream culture". No country or culture can override other countries or cultures.

Second is human holism and common interests. The concept of "common interest" is not always. In European monarchy, the interests of the state are the interests of the individual or family of the monarch. China takes a broad mind and a forward-looking mind to examine the global problems facing the globalization era. Extending the national perspective to the whole human perspective, advocating the true value of human beings. The expansion of public nature and altruism to the world rather than one country is directly related to the fundamental and long-term interests of the entire human society. As emphasized in the eighteen major reports, China will continue to combine the interests of the Chinese people with the common interests of all peoples. We should take a more active role in international affairs, play a role of a responsible big country and jointly tackle global challenges.

The third is a mutually beneficial and win-win cooperation view. With the deepening of globalization, the interdependence between the international community has been unprecedentedly 
strengthened. The human community is faced with a variety of global problems. Strengthening cooperation has become the proper choice for all countries. As general secretary Xi Jinping pointed out in the nineteen major report of the party, "no country can deal with the challenges of human beings alone, and no country can return to the isolated island of self." The traditional zero sum game, the traditional thinking that you win, lose, fight alone or unilateralism have been urgently needed by the new concept of mutual benefit and win-win.

The common interests are different from the public interests. Public interest is the intersection of people on the basis of personal interests, and it is the interests shared by all. Although the public interest has changed the nature of personal interests, its essence comes from personal interests, and public interest is part of the transfer of personal interests. Besides, fairness and justice, sustainable development and global governance provide basic values for building a community of human destiny. Economic globalization has prompted people to reflect on the traditional concept of national interests. The transmission mechanism of globalization in a moment and at the end of the earth has transformed the planet of human living into a "global village", and the high fusion of national interests has made the different countries a link of the chain of common interests. Common interests transcend the limitations of public interests. "Common interests are not personal gains, nor narrow bonuses". Common interests are "goodwill that human beings share and communicate with each other in essence". The idea of the community of human destiny starts from the height of safeguarding the interests of all mankind. Through peaceful development, seeking common ground while reserving differences, mutual respect, equal treatment, mutual help, mutual co construction and sharing of value consensus, and ultimately achieve win-win cooperation.

The common value is not the universal value. Any value has its own locality, and pure universal value does not exist. But any special value has the commonality of this era, and it has the common pursuit and hope of human beings for a better life. The Internet has closely linked all countries in an unprecedented way to launch cyber attacks at any point in the world, seemingly endless, but the loss to the economy and society of the country is likely to be less than a war. Therefore, the values of all nationalities and countries have certain commonality and universality, which is the common value of mankind. The so-called universal value is actually the value of the West advocating its value for all mankind, and is being enforced in other countries under the guise of universal value. Against this background, people also have a new understanding of common interests. Since human beings are already in the "earth village". Citizens of all countries, at the same time, are also citizens of the earth. The interests of the whole world are also their own interests. A country that takes advantage of global interests also serves its own interests at the same time. The common value is equal coexistence of multiple values, and its goal is to build a community of human destiny.

\section{Conclusion}

China is an advocate of the community of human destiny and a practitioner of human common values. All countries in the world have their own core interests, and accordingly produce corresponding diplomatic values. These values can be regarded as a different fulcrum in the international community. The common value of human beings is to bring these fulcrum or converge, or link together, to promote the establishment of a new order of global governance through co operation, co - governance and co - construction. It promotes the realization of common development and common prosperity of mankind. If politicians from all over the world can really consider the issue from the long-term interests of all mankind, instead of formulating policies from the perspective of short-term domestic political needs. A higher degree of community destiny towards common prosperity can be built. The community of human destiny is the contemporary form of the real community of mankind. Therefore, the construction of the human destiny community also needs to realize the harmonious symbiosis between man and nature, the multiple coexistence between people and the cooperation and win-win cooperation between China and the country. And constantly strive for the real solution of the contradiction between man and nature, between individual and class. 


\section{References}

[1] Roduit J A R. Rezension - The Politics of Emerging Strategic Technologies: Implications for Geopolitics,Human Enhancement and Human Destiny[J]. Zeitschrift für Lebensmittel-Untersuchung und -Forschung, 2012, 200(1):38-43.

[2] Green B L, Lewis R K, Wang M Q, et al. Powerlessness, Destiny, and Control: The Influence on Health Behaviors of African Americans[J]. Journal of Community Health, 2004, 29(1):15-27.

[3] Bayer R, Echeverria E J. The social nature of the human person in economic personalism[J]. Journal of Markets \& Morality, 2001, 4(4):511-525.

[4] Malouf D B, Schiller E P. Practice and research in special education.[J]. Exceptional Children, 1995, 61(5):414-424.

[5] Educationalinnovation C F. The Reversal of Gender Inequalities in Higher Education: An On-going Trend [J]. Sourceoecd Social Issues/migration/health, 2008, volume 2008(17): 338-379(42).

[6] Heyer K D. EDUCATION AS AN AFFIRMATIVE INVENTION: ALAIN BADIOU AND THE PURPOSE OF TEACHING AND CURRICULUM [J]. Educational Theory, 2009, 59(4):441-463.

[7] East L, Stokes R, Walker M. Universities, the public good and professional education in the UK [J]. Studies in Higher Education, 2014, 39(9):1617-1633.

[8] Reid D. School sex education and the causes of unintended teenage pregnancies: a review. [J]. Health Education Journal, 1982, 41(1):4-11.

[9] Bird G, Short J. COMMUNITY, IMMUNITY, AND THE PROPER an introduction to the political theory of roberto esposito[J]. Angelaki, 2013, 18(3):67-72.

[10] Wolman A. National Human Rights Commissions and Asian Human Rights Norms [J]. Asian Journal of International Law, 2013, 3(1):77-99. 